\title{
Germination and Early Seedling Growth of Moringa oleifera Lam with Different Seeds Soaking Time and Substrates at the Yongka Western Highlands Research Garden Park (YWHRGP) Nkwen-Bamenda, North-West Cameroon
}

\section{Bernard Palmer Kfuban Yerima1*, Grace Mbakpor Ayuk², Roger Kogge Enang1, Nicole Guehjung², Yanick Alphonse Tiamgne ${ }^{3}$}

${ }^{1}$ Department of Soil Science, University of Dschang, Dschang, Cameroon

${ }^{2}$ Department of Crop Production, University of Dschang, Dschang, Cameroon

${ }^{3}$ Ministry of Agriculture and Rural Development, West Region, Cameroon

Email: *bernardyerima@yahoo.com

How to cite this paper: Yerima, B.P.K., Ayuk, G.M., Enang, R.K., Guehjung, N. and Tiamgne, Y.A. (2016) Germination and Early Seedling Growth of Moringa oleifera Lam with Different Seeds Soaking Time and Substrates at the Yongka Western Highlands Research Garden Park (YWHRGP) NkwenBamenda, North-West Cameroon. American Journal of Plant Sciences, 7, 2173-2185. http://dx.doi.org/10.4236/ajps.2016.715192

Received: June 9, 2016

Accepted: November 4, 2016

Published: November 7, 2016

Copyright $\odot 2016$ by authors and Scientific Research Publishing Inc. This work is licensed under the Creative Commons Attribution International License (CC BY 4.0).

http://creativecommons.org/licenses/by/4.0/ (c) (i) Open Access

\begin{abstract}
Moringa oleifera is a multipurpose tree used to remedy problems related to food insecurity and soil fertility degradation. Proper husbandry of this crop is contingent on the use of seedlings of good quality. This study aimed at assessing the germination and early seedling growth with different soaking durations and substrates composition. The seeds were obtained from the Far North region of Cameroon. A randomized complete block design with three replications was used. Two factors were tested; soaking duration with 4 treatment levels of 0 day, 4 days, 8 days and 12 days and substrates with 8 treatment levels: $100 \%$ soil, $75 \%$ soil $+25 \%$ poultry manure (PM), 50\% soil $+50 \% \mathrm{PM}, 25 \%$ soil $+75 \% \mathrm{PM}, 100 \%$ sand, $75 \%$ sand $+25 \% \mathrm{PM}$, $50 \%$ sand $+50 \%$ PM and $25 \%$ sand $+75 \%$ PM. Germinated seeds and growth parameters were collected after every 5 days. The results showed that soaking duration and substrate composition influence germination and initial development of M. oleifera ( $\mathrm{p} \leq 0.05)$. At 25 days after soaking (DAS), soaking durations of 0 day (68.7\%) and 8 days (53.1\%) showed the highest germination percentages while seeds soaked for 12 days occupied the least position with $37.5 \%$. At the same time, $75 \%$ soil $+25 \%$ PM (68.7\%), 100\% sand (64.5\%) and $100 \%$ soil (60.5\%) with the unsoaked seeds showed the highest germination percentages. The least germination percentages were
\end{abstract}


represented by $50 \%$ sand $+50 \% \mathrm{PM}$ and $25 \%$ sand $+75 \% \mathrm{PM}$ with $35.5 \%$ and $27 \%$, respectively. Unsoaked seeds with the substrates of $50 \%$ soil $+50 \% \mathrm{PM}$ are the best practice for $M$. oleifera seedling production in the nursery.

\section{Keywords}

Soaking, Substrate Composition, Germination, Initial Growth, Western Highlands

\section{Introduction}

As a result of population growth and agricultural expansion, few forests are remaining and they are highly degraded, causing losses in traditionally important nutritious foods, medicines and other useful products leading to food insecurity [1] [2]. Furthermore, soil fertility has drastically fallen with fallow shortening and steadily disappearing to make room for continuous farming [1]. There is a need to develop emerging plants like Moringa. Moringa oleifera, also known as horse radish, benzolive tree or drumstick tree [3] [4] is one of the world's most useful and nutritious plants [4]. Moringa has both therapeutic and nutritional values. It is also used in animal forage, biogas, domestic cleaning, biopesticide and water purification [3]. In fact, almost all parts of the tree are useful and have long been consumed by humans [3]. It is the only genius of the family Moringaceae and is grown mainly in the semi-arid, the tropical and subtropical regions [3] [4]. It is adapted to a wide range of soil types but grows best in well drained loam to clay loam, neutral to slightly acidic soils, but cannot withstand prolonged water logging [5] [6]. It does best where temperatures range from $26^{\circ} \mathrm{C}-40^{\circ} \mathrm{C}$ and annual rainfall totals at least $500 \mathrm{~mm}$ [7]. Moringa is propagated sexually through seeds, and vegetatively through stem cuttings [4]. Its recent introduction as a field crop has required propagation through seeds which are usually planted in the nursery using a light media (3/1 proportion), mixture of soil and sand, respectively [4]. The germination of $M$. oleifera is hypogeal, meaning that the cotyledons remain beneath the soil surface [8]. [9] suggested that the use of garden/topsoil substrate leads to a germination percentage above $70 \%$ after three weeks. Germination occurs within 5 - 30 days, depending on the age of the seed, soil or media type and pretreatment method used, which might include: cracking the shells, soaking seeds with shells, dehulling seeds, and soaking seeds for 24 hours then putting in a plastic bag and storing in a warm place [8]. Some authors indicate the necessity of soaking or priming the seeds for 24 hours before sowing [6] [10] [11]. Soaking improves seed performance and provides faster and synchronized germination [6]. When factors like substrate quantity, hydric availability, thermal properties and absence of physical obstacles for the emergence of some species are improved, the seeds have better conditions for germination and emergence, and the seedlings better conditions for initial development [12].

Frequently, farmers are limited by the use of one or few commercial substrates, usually of high cost and not easily accessible, often not very common in the western 
highland regions of Cameroon, where there is a weak technical and commercial support for horticultural activities. However, in the above area, it is possible to find many byproducts from the traditional agriculture and livestock activities, which could be used in the formulation of competitive alternative substrates, of low cost. Knowledge on the optimum manure requirements would significantly assist in scaling up $M$. oleifera production as an edible vegetable. Previous works focused mainly on nutritional values and uses whilst research on establishment and growth has not received much attention despite the growing awareness that $M$. oleifera production can be adversely affected by nutrient status of soil or media [13]. Often during germination and growth of Moringa seeds, seedlings show symptoms of stunted growth and yellowing of leaves, resulting in death or reduced growth. This has been attributed to low initial soil nutrition and water logging in some cases [13]. There is therefore a need to use locally available soil fertility amendment resources such as poultry manure to improve the establishment and growth of Moringa in resource constrained soils of the Western highlands of Cameroon. [5] [14] have shown that poultry manure can serve as a soil amendment to improve soil nutrient status. It is a source of carbon and nitrogen for microorganisms in the soil, improves soil structure, lowers the temperature at the soil or media surface, helps in seed germination and increases water holding capacity particularly in sandy soils, stabilizes soil $\mathrm{pH}$, increases soil organic matter and ultimately improves plant growth and yields [14].

In Cameroon, there is little technical information on the production of quality seedlings of the Moringa plant except those of [10] [15] [16]. The latter authors discussed some aspects of germination but none addressed the influence of soaking and substrate composition with poultry manure on germination and seedling growth in the western highlands agro ecological zone. Considering the importance of Moringa, the present study was carried out with the objective of assessing the effect of four soaking durations and eight substrate compositions on the germination and initial seedling growth of Moringa in polyethylene bags in the nursery.

\section{Materials and Methods}

\subsection{Study Site}

The study was conducted from August to September 2013 at the Yongka Western Highlands Research Garden Park (YWHRGP), Nkwen-Bamenda located in the NorthWest region of Cameroon (Between Latitude $5^{\circ} 59^{\prime} 24^{\prime \prime}$ and $5^{\circ} 59^{\prime} 35^{\prime \prime} \mathrm{N}$; Longitude $10^{\circ} 2^{\prime} 5^{\prime \prime}$ and $\left.10^{\circ} 2^{\prime} 9^{\prime \prime} \mathrm{E}\right)$ at an altitude of $900-1000 \mathrm{~m}$ above sea level. Bamenda receives monomodal rainfall with a peak in August and having a mean annual precipitation of 2500 $\mathrm{mm}[2]$.

\subsection{Experimental Management}

Moringa seeds were sourced from local farmers in the Far North region of Cameroon (Sudano-Sahelian zone with $400-900 \mathrm{~mm}$ of rainfall [16]. The seed lots were sieved to remove debris and sorted based on their size and color. A viability test was carried out by removal of seeds that floated after a short time. Good seeds were sundried to prevent 
imbibitions, which would have an adverse effect on the experimental variable (soaking). The seeds had an average weight of $0.25 \mathrm{~g}$.

The experiment was a factorial design laid down in a randomized complete block with two factors. The variables were soaking duration with 4 treatment levels of 0 day, 4 days, 8 days and 12 days and substrates with 8 treatment levels: $100 \%$ soil (4 buckets of soil); $75 \%$ soil $+25 \%$ PM ( 3 buckets of soil/1 bucket of PM); $50 \%$ soil $+50 \%$ PM (2 buckets of soil/2 buckets of PM); $25 \%$ soil $+75 \% \mathrm{PM}$ ( 1 bucket of soil/3 buckets of PM); $100 \%$ sand ( 4 buckets of sand); $75 \%$ sand $+25 \%$ PM ( 3 buckets of sand/1 bucket of $\mathrm{PM}) ; 50 \%$ sand $+50 \% \mathrm{PM}$ ( 2 buckets of sand $/ 2$ buckets of $\mathrm{PM}) ; 25 \%$ sand $+75 \% \mathrm{PM}(1$ bucket of sand/3 buckets of $\mathrm{PM}$ ). Each treatment was replicated three times, giving a total of 96 experimental units of 4 pots each.

The soil used was the topsoil of a Hapli-skeletic Cambisol of the YWHRGP. The sand was collected from the crossing German trench where it is equally fetched by the local populations for constructions. The poultry manure was obtained from a local farmer in Bamenda. The different substrate mixes were obtained from a number of buckets of soil, sand and PM depending upon the amount required. A 10 liter bucket was used to measure the different materials in their different proportions as indicated above and was properly mixed with the hands as is customary with the farmers in the field. These substrates (soil, sand and PM) were chosen because of their availability to farmers. Equally some of these substrates are widely used in the production of seedlings of different annual plants, fruit and forestry species [12]. The soaked seeds were obtained by soaking 3 lots of 96 seeds for 12 days, 8 days, and 4 days, respectively. The soaked seeds with the 96 unsoaked seeds (control) were planted the same day [6]. The sowing was conducted on the $18^{\text {th }}$ of August 2013 in filled polyethylene bags $(17 \times 10 \mathrm{~cm})$ at $3 \mathrm{~cm}$ depths (three times the grain diameter) and the top of the bags were covered with hashed dry grass to prevent splash soil loss.

\subsection{Data Collection and Analysis}

Germination was monitored through the counting of germinated seedlings after every five days for a period of 25 days. According to [6] [12] [16], evaluation of germination is stopped 25 - 30 days after sowing. A Moringa seed is considered germinated when the stalk appears above the ground [16]. For early seedling growth, seedlings from the previous test were monitored and maintained until the $45^{\text {th }}$ day after sowing. The height and collar circumference of seedlings were measured using a tape. In addition, the number of leaves was determined. This evaluation was done every 5 days. Data collected were subjected to analysis of variance and graphical representations. Significant means were separated by the Duncan multiple range test (DMRT). The statistical packages used were Microsoft Excel 2010 and SPSS 19.0 for Windows.

\section{Results and Discussions}

\subsection{Seed Germination}

The germination of Moringa oleifera as a function of soaking treatment and substrate 
compositions at $\mathrm{p} \leq 0.05$ is presented in Table 1 . The first seeds began to germinate 5 DAS. Regarding the evolution of germination, unsoaked seeds (38.5\%) and substrate of $100 \%$ soil (39.5\%) exhibited the highest germination percentages at 5 DAS (Figure 1). The lowest percentages were observed on 12 days soaked seeds (9.4\%) and substrate of $25 \%$ sand $+75 \%$ PM (8.2\%). Seeds of soaking treatments almost doubled their percentage of germination at 15 DAS. At the same time, substrates of $100 \%$ soil (58.2\%), $75 \%$ soil $+25 \%$ PM (54.2\%), 100\% sand (50\%) and 75\% sand $+25 \%$ PM (50\%) presented the highest germination percentages. They were followed by substrates of $50 \%$ soil $+50 \%$ PM (45.7\%) and 25\% soil + 75\% PM (41.7\%).

Unsoaked seeds and seeds from nearly all the substrates (50\% sand + 50\% PM, 25\% sand $+75 \%$ PM, $100 \%$ soil, $50 \%$ soil $+50 \%$ PM and $25 \%$ soil $+75 \% \mathrm{PM})$, ceased to germinate 20 DAS, while those from $100 \%$ sand, $75 \%$ sand $+25 \%$ PM, $75 \%$ soil $+25 \%$ PM, 4 days soaking, 8 days soaking and 12 days of soaking reached the $25^{\text {th }}$ DAS (Figure 1). Substrates of $75 \%$ soil $+25 \%$ PM $(68.7 \%), 100 \%$ sand $(64.5 \%)$ and $100 \%$ soil $(60.5 \%)$ presented the highest germination percentages. They were followed by substrates of $50 \%$ soil $+50 \%$ PM $(58.5 \%), 75 \%$ sand $+25 \%$ PM $(58.3 \%)$ and $25 \%$ soil + $75 \%$ PM (56.3\%). The least germination percentages were occupied by substrates of $50 \%$ sand $+50 \% \mathrm{PM}$ and $25 \%$ sand $+75 \%$ PM with $35.5 \%$ and $27 \%$ germination, respectively (Table 1$)$.

Table 1. Effect of soaking and substrate compositions on Moringa oleifera Lam. Seeds.

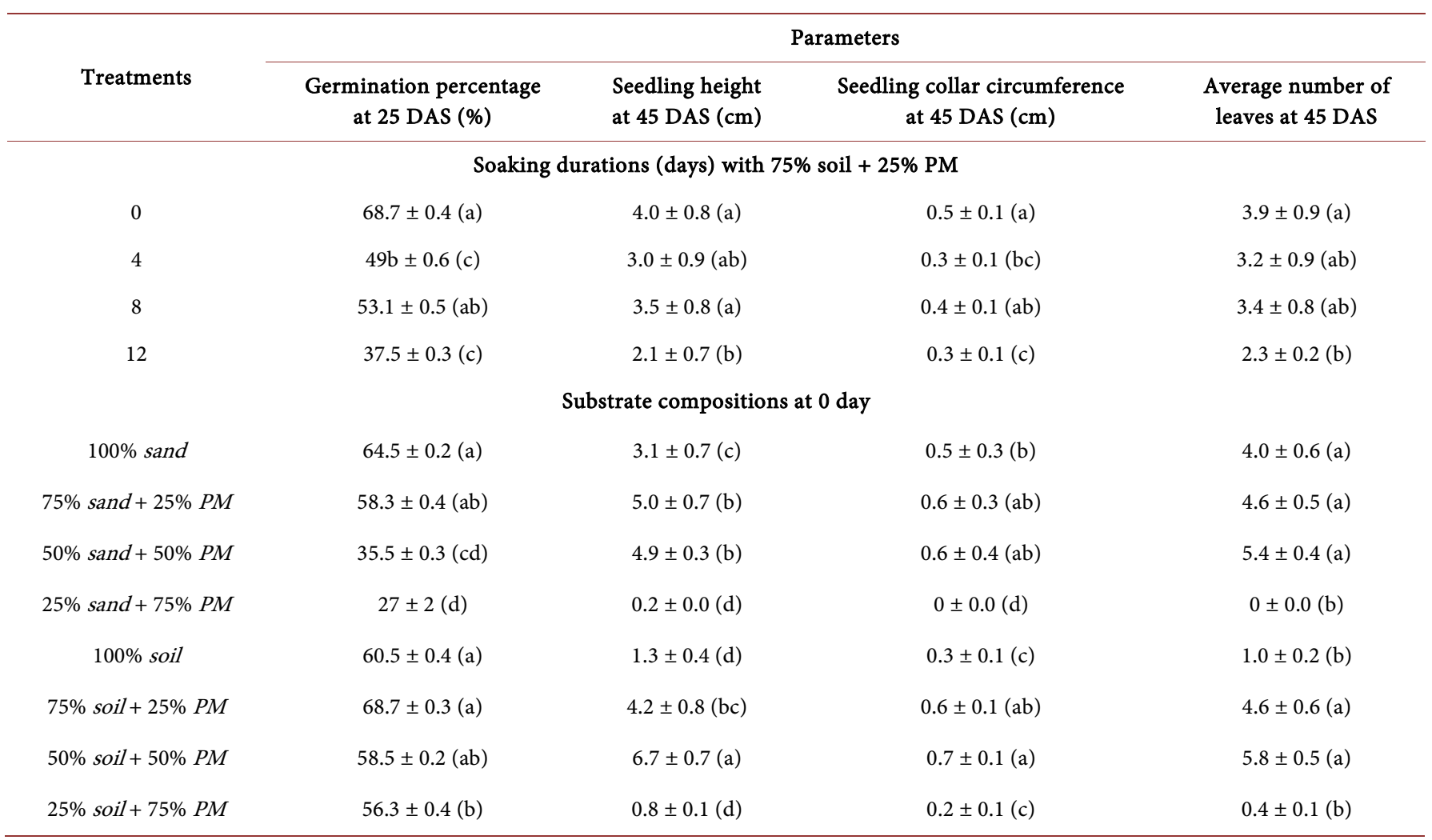

NB: values in the table are means $+/$ - relative standard deviation (RSD). Means followed by the same letter in the same column are not significantly different ( $\mathrm{p} \leq$ 0.05). DAS $=$ Days after sowing, $\mathrm{PM}=$ Poultry Manure. 


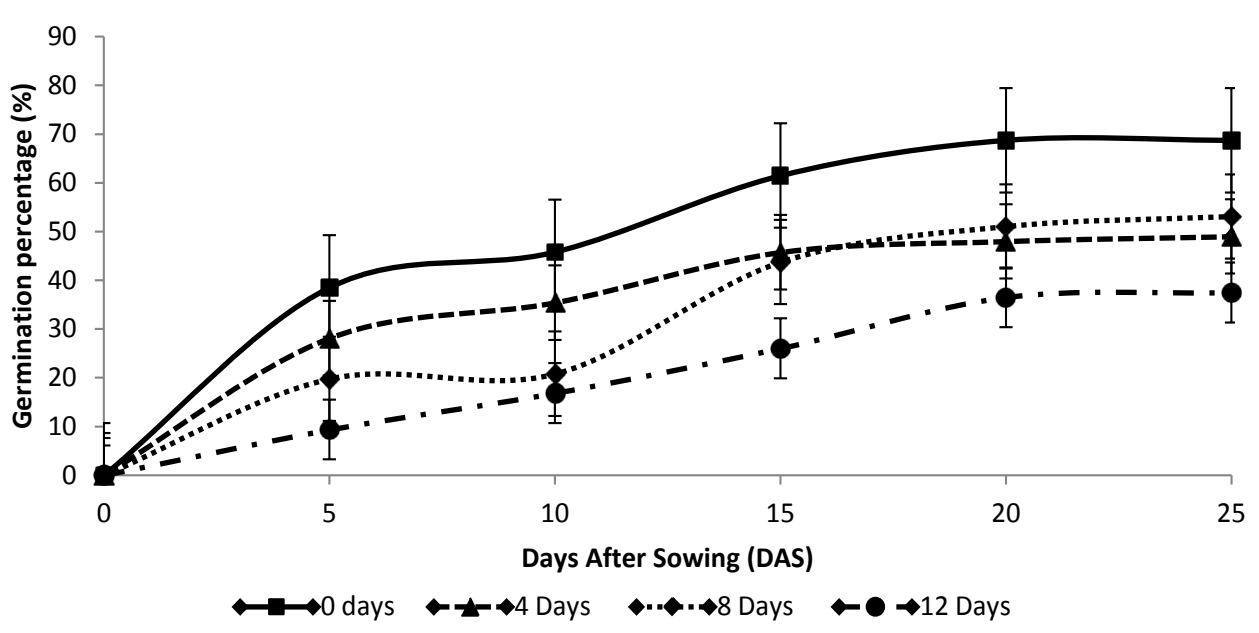

(a)

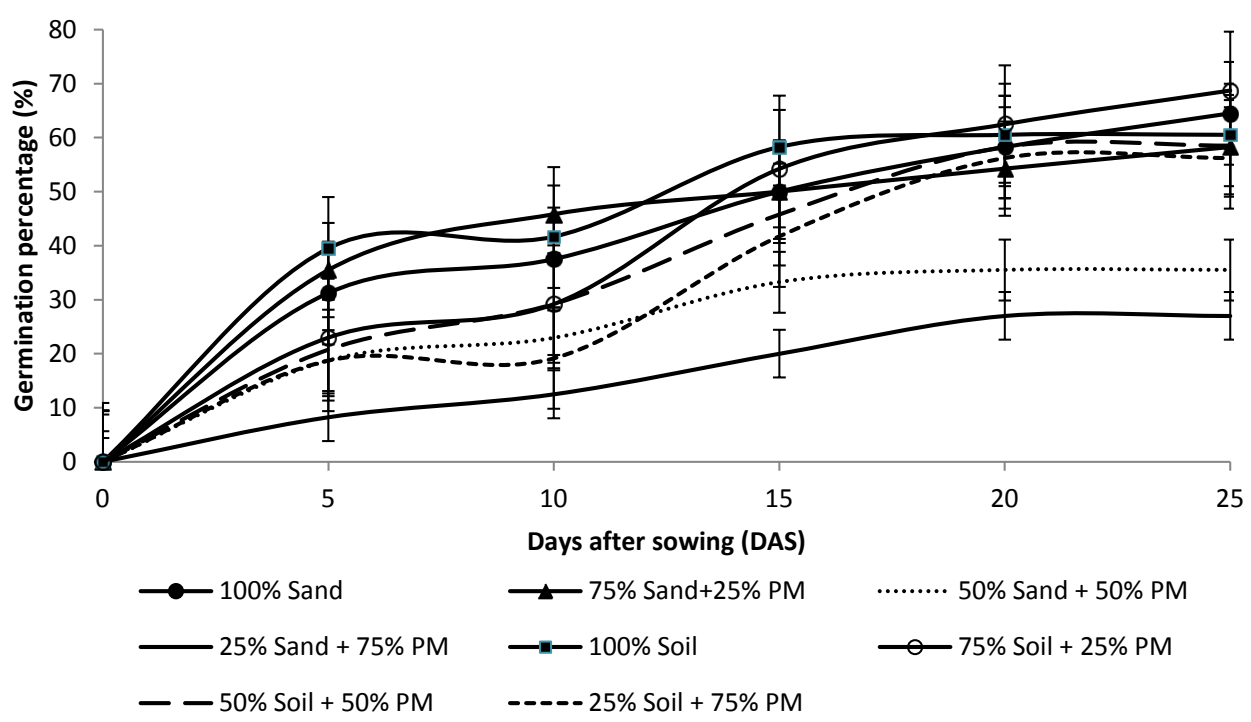

(b)

Figure 1. Daily variation of germination percentage of $M$. oleifera with (a) soaking durations with $75 \%$ soil $+25 \%$ PM and (b) substrate compositions at 0 day.

\subsection{Initial Growth of Seedlings}

Seedling growth in height, collar circumference and average number of leaves was significantly influenced by the soaking duration and substrates composition 45 DAS as shown in Table 1. At 25 DAS, the average seedling height varied from $3.1 \mathrm{~cm}$ for seedlings derived from the germination of unsoaked seeds to $1.2 \mathrm{~cm}$ for seedlings derived from the germination of seeds soaked for a period of 12 days (Figure 2(a)). The same situation was observed at 45 DAS with heights of $4 \mathrm{~cm}$ and $2.1 \mathrm{~cm}$ for seedlings from unsoaked seeds and 12 days soaked seeds, respectively.

Regarding the significance, height of seedlings from unsoaked seeds $(3.5 \mathrm{~cm}), 4$ days soaked seeds $(2.7 \mathrm{~cm})$ and 8 days soaked seeds $(2.9 \mathrm{~cm})$ was not different at 25 DAS and 45 DAS, respectively. Average height of seedlings derived from all the substrates composition was between $4.5 \mathrm{~cm}(50 \%$ soil $+50 \% \mathrm{PM})$ and $0.01 \mathrm{~cm}(25 \%$ sand $+75 \% \mathrm{PM})$ 


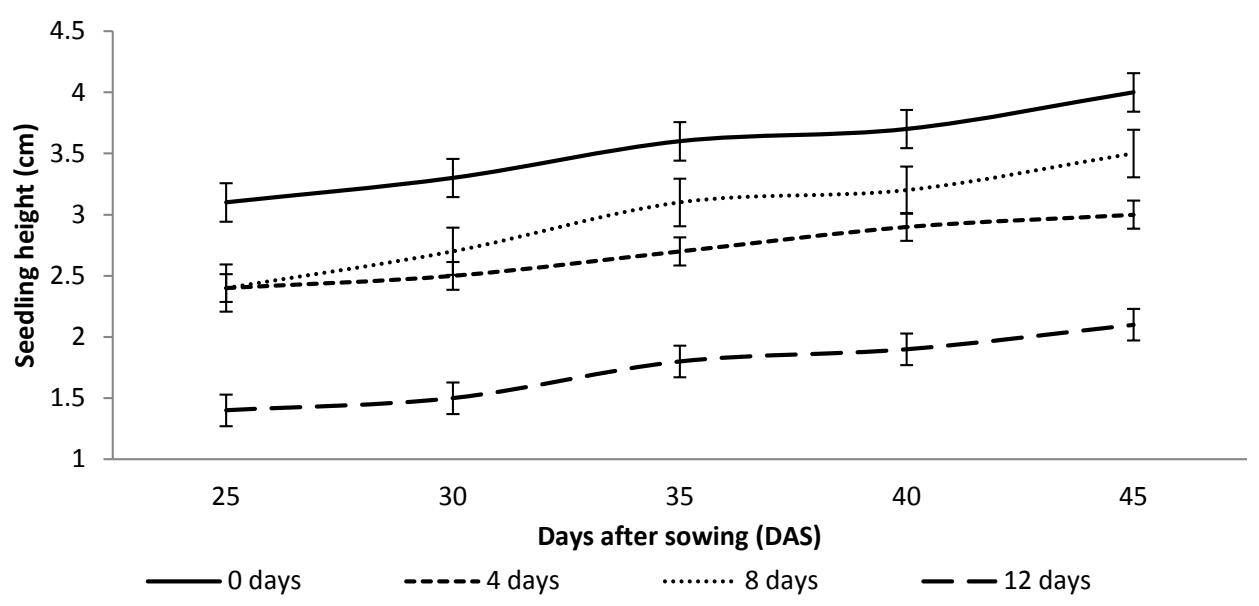

(a)

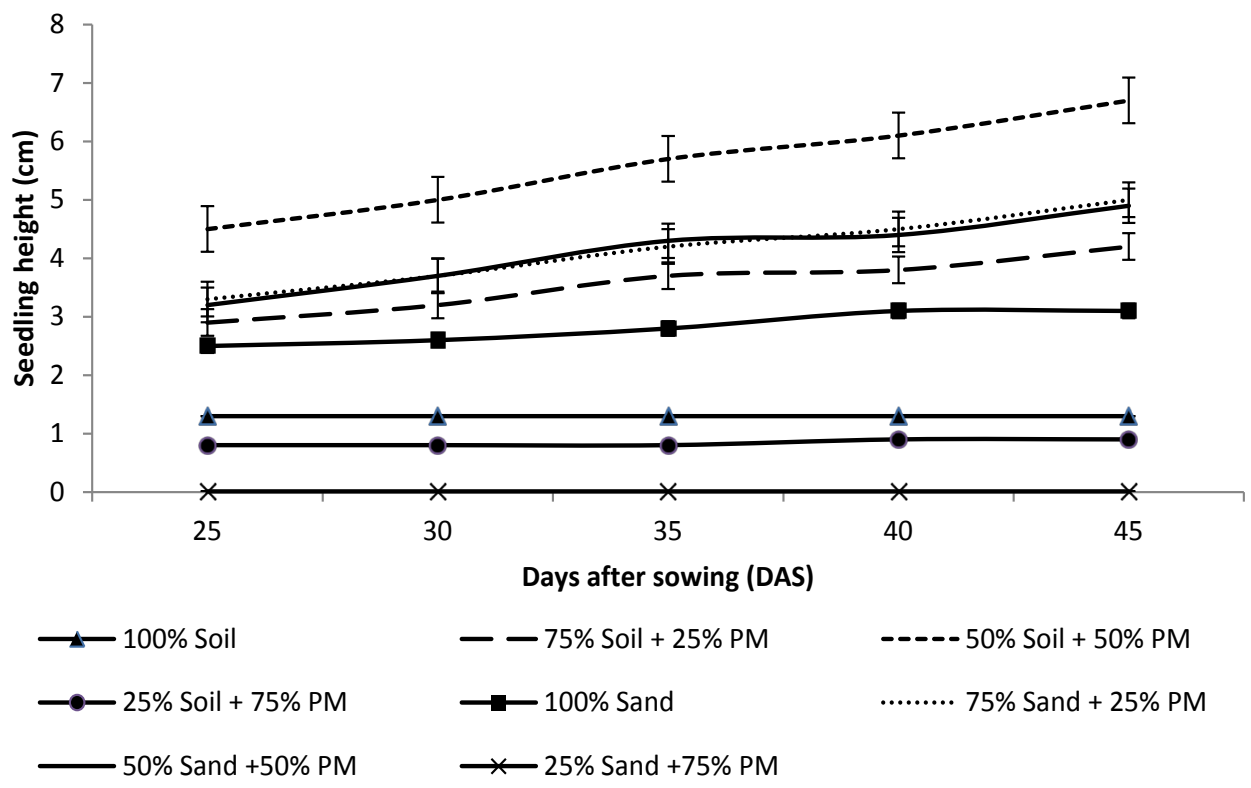

(b)

Figure 2. Daily variation of vertical seedlings growth of $M$. oleifera with soaking durations (a) and substrate compositions (b).

at 25 DAS (Figure 2(b)). At 45 DAS, seedlings derived from the $50 \%$ soil $+50 \% \mathrm{PM}$ was the highest with $6.7 \mathrm{~cm}$. They were followed by substrates of $75 \%$ soil $+25 \% \mathrm{PM}$ $(5.0 \mathrm{~cm}), 50 \%$ sand $+50 \% \mathrm{PM}(4.9 \mathrm{~cm})$ and $75 \%$ soil $+25 \% \mathrm{PM}(4.2 \mathrm{~cm})$. The least average height was occupied by seedlings germinated on substrates of $100 \%$ soil $(1.3 \mathrm{~cm})$, $25 \%$ soil $+75 \% \mathrm{PM}(0.8 \mathrm{~cm})$ and $25 \%$ sand $+75 \% \mathrm{PM}(0.2 \mathrm{~cm})$.

For the radial growth, the average collar circumference of the stems of seedlings was $0.3 \mathrm{~cm}, 0.2 \mathrm{~cm}, 0.3 \mathrm{~cm}$ and $0.2 \mathrm{~cm}$ for seedlings originating from 0 day, 4 days, 8 days and 12 days soaked seeds at 25 DAS, respectively (Figure 3(a)). At 45 DAS, seedlings derived from the germination of 0 day, 4 days, 8 days and 12 days soaked seeds exhibited average collar circumferences of $0.5 \mathrm{~cm}, 0.3 \mathrm{~cm}, 0.4 \mathrm{~cm}$ and $0.3 \mathrm{~cm}$, respectively. There was no significant difference $(\mathrm{p} \leq 0.05)$ between seedlings deriving from 0 day 


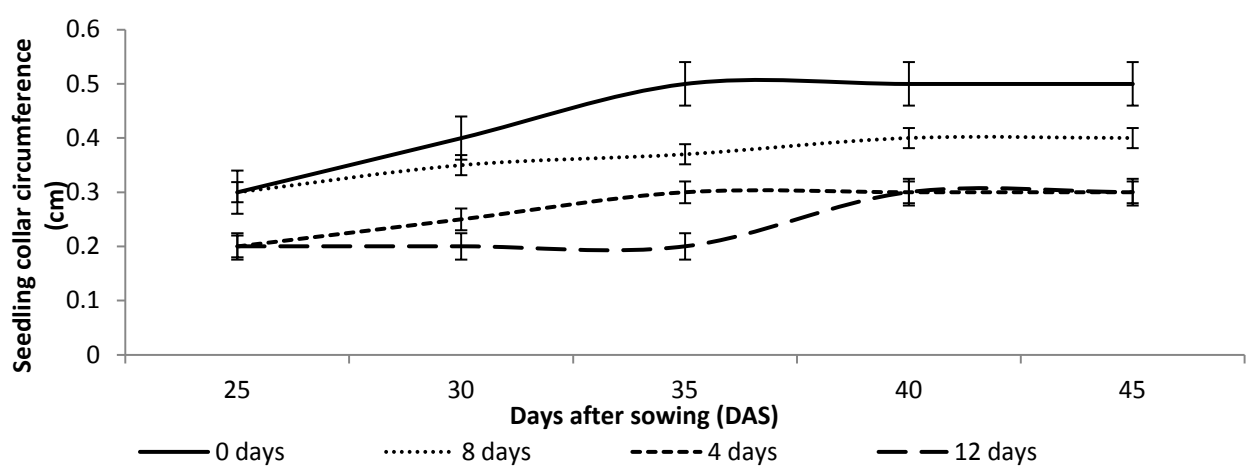

(a)

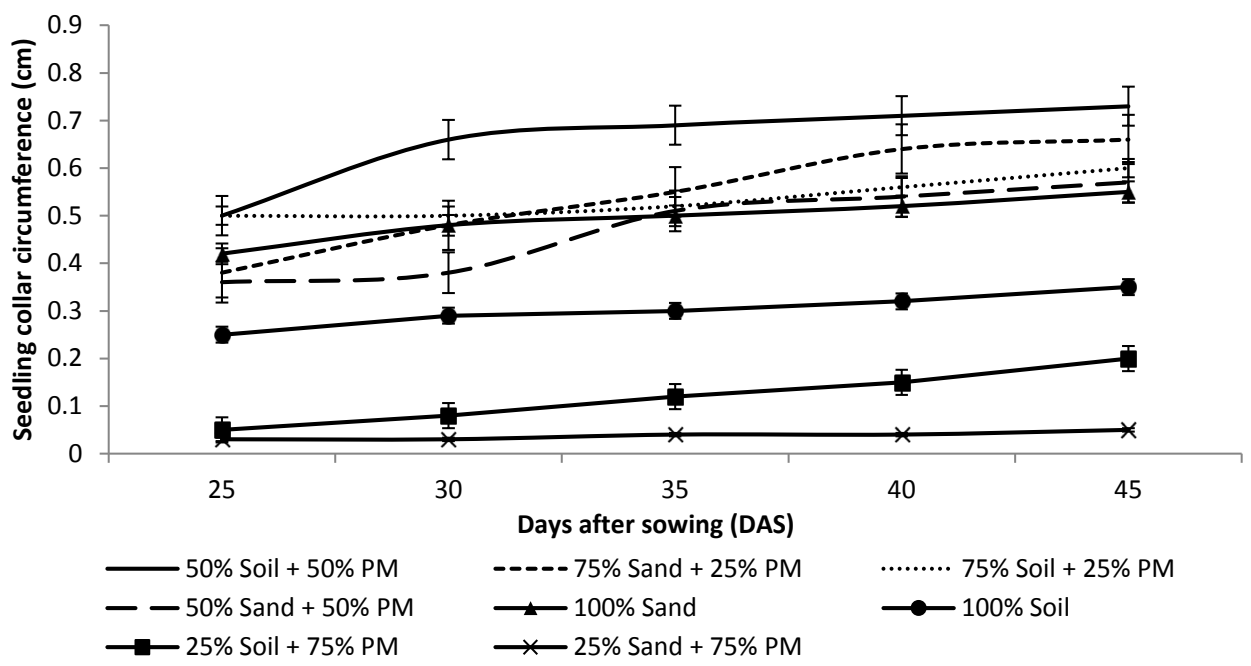

(b)

Figure 3. Daily variation of seedlings collar circumference of $M$. oleifera with soaking durations (a) and substrate compositions (b).

and 8 days soaked seeds. Stems of seedlings of all the substrates had collar circumferences below $1 \mathrm{~cm}$ during the observation period of the experiment (Figure 3(b)).

Highest collar circumferences were obtained on seedlings of $50 \%$ sand $+50 \%$ PM $(0.5 \mathrm{~cm})$ and $50 \%$ soil $+50 \% \mathrm{PM}(0.5 \mathrm{~cm})$ one month after sowing. They were followed by those from $100 \%$ sand, $75 \%$ sand $+25 \%$ PM and $75 \%$ soil $+25 \%$ PM exhibiting average collar circumferences of $0.4 \mathrm{~cm}$ each. Seedlings from substrates of $100 \%$ soil $(0.3$ $\mathrm{cm}), 25 \%$ soil $+75 \% \mathrm{PM}(0.2 \mathrm{~cm})$ and $25 \%$ soil $+75 \% \mathrm{PM}(0.03 \mathrm{~cm})$ were not well developed after one month of growth. The best average collar circumference was expressed on substrates with 50\% soil $+50 \% \mathrm{PM}$ at 45 DAS with a value of $0.7 \mathrm{~cm}$ (Figure $3(\mathrm{~b})$ ). It was followed by seedlings derived from substrates of $50 \%$ sand $+50 \% \mathrm{PM}, 75 \%$ sand $+25 \% \mathrm{PM}$ and $75 \%$ soil $+25 \% \mathrm{PM}$ with a value of $0.6 \mathrm{~cm}$ each. The worst substrate was $25 \%$ sand $+75 \%$ PM $(0.05 \mathrm{~cm})$ (Figure $3(\mathrm{~b})$ ).

At day 45 , the average number of leaves per seedling was influenced by soaking times and substrates compositions. Regarding effect of soaking, extreme values corresponded to the seedlings with the following soaking durations: unsoaked seeds (3.9) and 12 days soaked seeds (2.3) (Table 1 and Figure 4(a) and Figure 4(b)). 


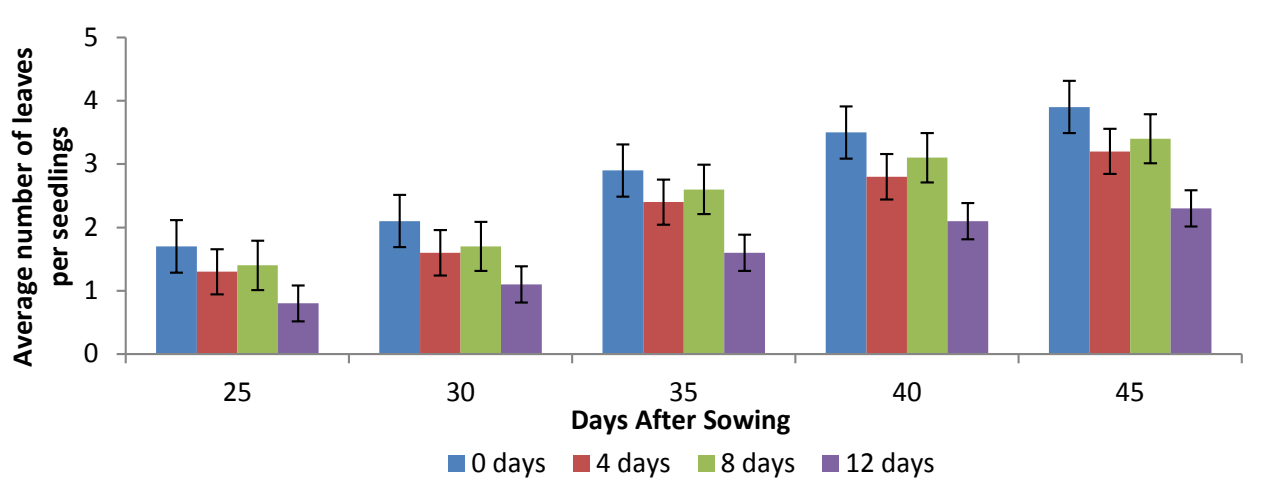

(a)

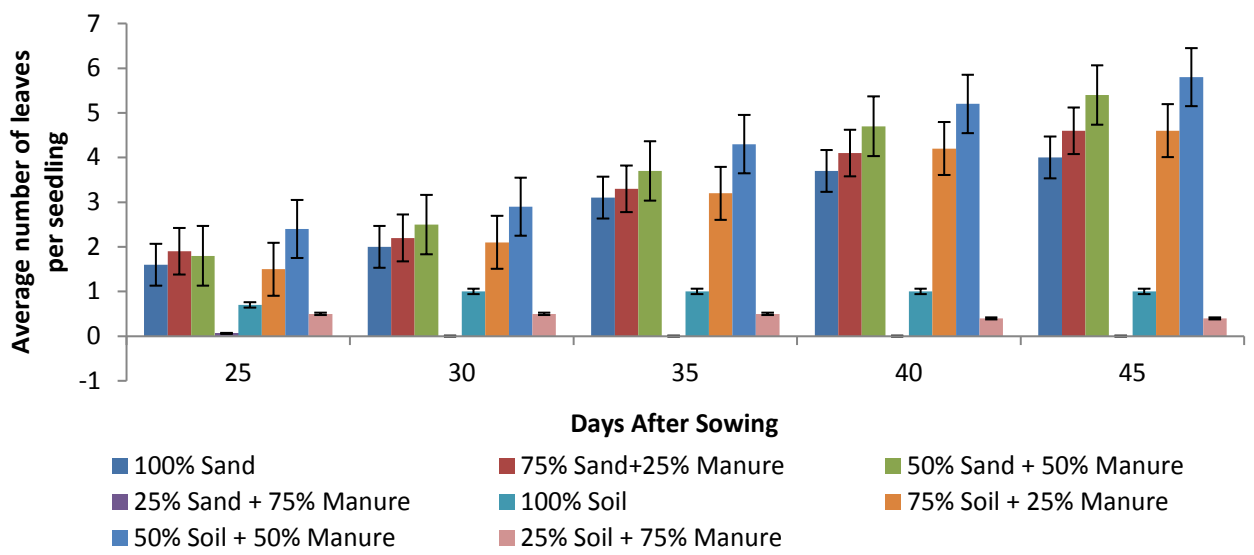

(b)

Figure 4. Daily variation of average number of leaves of $M$. oleifera seedlings with Soaking durations (a) and substrate compositions (b).

Plants derived from seeds of 0 day, 4 days and 8 days soaking durations had the same statistical average number of leaves with values of 3.9, 3.2 and 3.4 leaves, respectively. The effect of substrates composition was expressed through two sets of average number of leaves which are firstly 50\% soil $+50 \% \mathrm{PM}, 50 \%$ sand $+50 \% \mathrm{PM}, 75 \%$ soil $+25 \%$ $\mathrm{PM}, 75 \%$ sand $+25 \% \mathrm{PM}$ and $100 \%$ sand with 5.8, 5.4, 4.6, 4.6 and 4 leaves, respectively. Secondly, the set of seedlings grown on substrates of $100 \%$ soil, $25 \%$ soil $+75 \% \mathrm{PM}$, and $25 \%$ sand $+75 \%$ PM had the lowest number of leaves with 1, 0.4 and 0 leaves, respectively.

The substrate made up of $50 \%$ soil $+50 \%$ PM is the best media for $M$. oleifera initial growth (Figures 2-4). An 8 days period has been shown as the maximum period to soak M. oleifera seeds.

\subsection{Effect of Soaking on Seed Germination and Early Seedling Development}

Seed germination is initiated through rapid water uptake, followed by the activation of metabolic mechanisms leading to the first visual signs of germination known as the protrusion of the radical [8]. Thus, water plays a fundamental role in understanding seed biology, particularly germination and plant development. The principal factors in- 
fluencing seed germination are temperature, water, oxygen and light. Temperature is the most important, as it affects both the germination percentage and germination rate [8]. At 25 DAS, soaking durations of 0 day (68.7\%) and 8 days (53.1\%) showed the highest germination percentages, while seeds soaked for 12 days occupied the least position (37.5\%). The highest germination percentage of $68.7 \%$ is in agreement with the results obtained by [16] in the sudano-sahelian zone of Cameroon, where $69.6 \%$ of seeds had germinated at $25 \mathrm{DAS}$. The average percentages of germination of this plant in India, West Africa and other zones of Cameroon, were all above those obtained in this study. Different pretreatments (soaking, scarification) and differences in the agro ecological zones are likely responsible.

Although, some scientific results show that soaking is an option for improving the Moringa seed germination, other reports consider it unnecessary [6]. Seed priming improves germination and stand establishment and induces tolerance against adverse conditions like abiotic stress, especially during emergence and early seedling growth [11]. Moringa seeds are not an exception, and it was reported that $12 \mathrm{~h}$ of soaking increased the germination of moringa seeds in the western highlands of Cameroon [10]. Our results demonstrate that long duration (more than 8 days) pre-hydration negatively influences the germination process as well as the post germination behavior which probably affects the establishment in the field. Besides, it was demonstrated that pregermination for $48 \mathrm{~h}$ affects the percentage of seed germination negatively. This could be due to the fact that seeds soaked for a long time, can undergo putrefaction due to fungi attack [6]. The results obtained in this study when soaking duration reached 12 days is in conformity with those of the latter investigators. When the germination percentage was analyzed, the control (unsoaked seeds) attained $68.7 \%$. This confirms that seeds of this plant achieve high germination in spite of pre-germination treatments [6] [8]. Watering of the germination bags every day by rain until field capacity was attained could be another factor influencing germination. [6] stated that the excess of humidity on the substrate may provoke germination losses and diminishing of the root growth and the aerial part of some tree species like moringa. Average heights of seedlings from unsoaked seeds $(3.5 \mathrm{~cm}), 4$ days soaked seeds $(2.7 \mathrm{~cm})$ and 8 days soaked seeds $(2.9 \mathrm{~cm})$ were not significantly different overtime. Seedlings from 0 day, 4 days, 8 days and 12 days soaked seeds exhibited average collar circumferences of $0.5 \mathrm{~cm}, 0.3 \mathrm{~cm}, 0.4 \mathrm{~cm}$ and $0.3 \mathrm{~cm}$, respectively. zero day, 4 days and 8 days soaking durations had the same statistical average number of leaves with 3.9, 3.2 and 3.4 leaves, respectively.

Growth parameters were influenced by soaking treatments but unsoaked seeds, 4 days soaked seeds and 8 days soaked seeds expressed statistically the same average seedling height, collar circumference and number of leaves. In terms of height, seedlings derived from unsoaked seeds showed a value of $4 \mathrm{~cm}$ which is in contrast with the results of [16] but in line with those of [17]. The vertical growth of seedlings is low compared to results obtained by other investigators in Cameroon, working in warmer agro ecological zones. [16] carried out their study in Maroua (Sudano-sahelian zone) where evapotranspiration rates and mean annual temperatures are higher than those in 
the western highlands. Ambient temperatures have been reported to have a great influence on germination and seedling development [8].

\subsection{Effect of Substrate Composition on Seed Germination and Early Seedling Development}

Moringa is adapted to a wide range of soil types but grows best in well drained loam to clay loam, neutral to slightly acidic soils, but cannot withstand prolonged water logging [5] [6]. Its recent introduction as a field crop has required propagation through seeds which are usually planted in the nursery using a light media of $3 / 1$ proportion mixture of soil and sand, respectively [4]. [9] suggested that the use of garden/topsoil leads to a germination percentage above $70 \%$ after three weeks. Germination occurs within 5 - 25 days, depending on the soil or media type and pretreatment method used. At 25 DAS, substrates of $75 \%$ soil $+25 \%$ PM (68.7\%), $100 \%$ sand (64.5\%) and $100 \%$ soil $(60.5 \%)$ presented the highest germination percentages, followed by substrates of $50 \%$ soil + $50 \%$ PM (58.5\%), 75\% sand $+25 \%$ PM (58.3\%) and $25 \%$ soil $+75 \%$ PM (56.3\%). The least germination percentages were occupied by substrates of $50 \%$ sand $+50 \% \mathrm{PM}$ and $25 \%$ sand $+75 \%$ PM with $35.5 \%$ and $27 \%$ germination, respectively (Table 1 ). These results can be explained by the different levels of water holding capacity, associated with varying porosities and nutrient status of these substrates [18]. Equally, the watering of the germination bags every day by rainfall could result in leaching losses given that poultry manure is very soluble. This is in agreement with observations by [6] that the excess of humidity on the substrate with manure may provoke germination losses and diminishing of the root growth and the aerial part of some tree species like Moringa. The slightly lower germination with substrates with high poultry manure levels could also be associated with illuviation of manure into the subsurface resulting in compression of the substrate and crust formation, and reduced aeration resulting in root asphyxiation [12] leading to a reduction of the germination and emergence process. Equally, an increase in the substrate temperature near to the seed associated with the fermentation of manure, may have affected the germination and emergence process. Milder temperatures associated with the heat evolution from seeds on the substrate $75 \%$ soil $+25 \%$ PM may have an opposite effect, while the thin dry layer of residue from poultry manure on the seed absorbs moisture from the surrounding soil to the advantage of the seed [5].

Seedlings of $50 \%$ soil $+50 \%$ PM produced the highest height $(6.7 \mathrm{~cm})$, followed by substrates of $75 \%$ soil $+25 \%$ PM $(5.0 \mathrm{~cm}), 50 \%$ sand $+50 \%$ PM $(4.9 \mathrm{~cm})$ and $75 \%$ soil + $25 \%$ PM $(4.2 \mathrm{~cm})$. The best average collar circumference was expressed on the $50 \%$ soil $+50 \% \mathrm{PM}(0.7 \mathrm{~cm})$. Average number of leaves for the $50 \%$ soil $+50 \% \mathrm{PM}, 50 \%$ sand + $50 \%$ PM, 75\% soil $+25 \% \mathrm{PM}, 75 \%$ sand $+25 \% \mathrm{PM}$ and $100 \%$ sand were $5.8,5.4,4.6$, 4.6 and 4 leaves, respectively. The higher initial growth of seedlings was observed with the use of poultry manure in the mix with soil or sand in equal proportions. The higher availability of nutrients, increasing the growth of seedlings in relation to other substrates [12], may account for this behavior. This is consistent with the numerous ad- 
vantages provided by PM reported by [5] [14]. The consistent poor performance of highly fertilized plants and those planted with no manure reveals that when manure is available in adequate amounts, plants tend to grow at their optimal potential [5]. Knowledge on optimum manure requirements would significantly assist in scaling up $M$. oleifera production as an edible vegetable because often during its germination and growth, the seedlings show symptoms of stunted growth and yellowing of leaves, resulting in reduced growth or death. This has been attributed to low initial soil nutrition and water logging in some cases [13]. There is therefore need to use locally available soil fertility amendment resources such as poultry manure to improve the establishment and growth of Moringa in resource constrained farmers of the western highlands of Cameroon.

Besides, there is a significant production of many by-products from agriculture which can replace commercial substrates thereby reducing the production costs and thus increasing the economic gains. This knowledge has potential for formulation of new substrates, using available raw materials for distribution to other agro ecological zones.

\section{Conclusion}

The use of unsoaked seeds on substrates with $75 \%$ soil $+25 \%$ PM provided the best germination and emergence rates. The initial development is higher in substrates containing adequate proportions of poultry manure like 50\% soil + 50\% PM with unsoaked seeds. The use of prolonged soaked seeds (more than 8 days) with high levels of manure substrates must be avoided in the propagation of this crop, because it can affect its emergence and initial development negatively.

\section{References}

[1] Asaah, et al. (2009) Agroforestry Making the Difference in the Western Highlands of Cameroon. ICRAF-WCA Annual Report, 18-20.

[2] Yerima, B.P.K. (2010) Protective Measures Taken for Preserving Species Endangered of Extinction Due to the Climate Change in Yongka Western Highlands Research Garden-Park, Nkwen-Bamenda, NW Region, Cameroon. Support Africa International, 4-11.

[3] Igwilo, et al. (2013) Effect of Soaked Moringa oleifera Seeds on Growth Rates and the Levels of Some Biochemical Parameters in Albino Rats. Pakistan Journal of Biological Sciences, 16, 48-50. http://dx.doi.org/10.3923/pjbs.2013.48.50

[4] Mubvuma, M.T., Mapanda, S. and Mashonjowa, E. (2013) Effect of Storage Temperature and Duration on Germination of Moringa (Moringa oleifera) Seeds. Greener Journal of Agricultural Sciences, 3, 427-432.

[5] Adebayo, A.G., Akintoye, H.A., Olufolaji, A.O., Aina, O.O., Olatunji, M.T. and Shokalu, A.O. (2011) Assessment of Organic Amendments on Vegetative Development and Nutrient Uptake of Moringa oleifera Lam in the Nursery. Asian Journal of Plant Sciences, 10, 74-79. http://dx.doi.org/10.3923/ajps.2011.74.79

[6] Padilla, C., Fraga, N. and Suarez, M. (2012) Effect of Soaking Time of Moringa (Moringa oleifera) Seeds on the Germination and Growth Indicators of the Plant. Cuban Journal of Agricultural Science, 46, 419-421. 
[7] Goss, M. (2007) A Study on Initial Establishment of Multipurpose Moringa (Moringa oleifera Lam.) with Focus on Stand Densities, Nitrogen, Phosphorus, pH, Media Type and Seed Priming. M.Sc. Thesis, University of Zimbabwe, Zimbabwe.

[8] Quintin, E.M. (2009) Seed Germination, Tree Growth and Flowering Responses of Moringa oleifera Lam. (Horse Radish Tree) to Temperature. M.Sc. Thesis, University of Pretoria, Pretoria.

[9] WAC (2002) Moringa, Family: Moringaceae. World Agroforestry Center, Information Slip, 1-2.

[10] Pamo, T.E., Boukila, B., Tedonkeng, F., Kana, J.R., Tonfack, L.B. and Momo, M.C.S. (2004) Potentiel de germination de Moringa oleifera Lam sous différents traitements à Dschang dans les Hautes terres de l'Ouest-Cameroun. Journal of the Cameroon Academy of Sciences, 4, 199-203.

[11] Nouman, W., Siddiqui, M.T., Basra, S.M.A., Afzal, I. and Rehman, H.U. (2012) Enhancement of Emergence Potential and Stand Establishment of Moringa oleifera Lam. by Seed Priming. Turkish Journal of Agriculture and Forestry, 36, 227-235.

[12] Piva, et al. (2013) Emergence and Initial Development of Cape Gooseberry (Physalis peruviana) Seedlings with Different Substrates Compositions. African Journal of Agricultural Research, 8, 6579-6584. http://dx.doi.org/10.5897/AJAR2013.6787

[13] Pahla, I., Tagwira, F., Muzemu, S. and Chitamba, J. (2013) Effects of Soil Type and Manure Level on the Establishment and Growth of Moringa oleifera. International Journal of Agriculture and Forestry, 3, 226-230.

[14] Yerima, B.P.K., Tiamgne, Y.A. and Van Ranst, E. (2014) Réponse de deux variétés de tournesol (Helianthus sp.) à la fertilisation à base de fiente de poule sur un Hapli-humic Ferralsol du Yongka Western Highlands Research Garden Park (YWHRGP) NkwenBamenda, Cameroun, Afrique centrale. Tropicultura, 32, 168-176.

[15] Madi, G. (2008) Croissance et colonisation mycorhizienne de Moringa oleifera en fonction d'utilisation des terres dans quelques localités dans la région de forêt humide du Cameroun. M.Sc. Thesis, University of Dschang, Dschang.

[16] Bayé-Niwah, C. and Mapongmetsem, P.M. (2014) Seed Germination and Initial Growth in Moringa oleifera Lam. 1785 (Moringaceae) in Sudano-Sahelian Zone. International Research Journal of Plant Science, 5, 23-29.

[17] Njehoya, C.A., Bourou, S., Awono, P.M.D. and Bouba, H. (2014) Evaluation du potentiel de germination de Moringa oleifera dans la zone soudano-guinéenne du Cameroun. Journal of Applied Biosciences, 74, 6141-6148. http://dx.doi.org/10.4314/jab.v74i1.5

[18] Mazarura, U., Goss, M. and Macherera, G. (2013) Effect of Media Type on Initial Establishment and Early Growth of Multipurpose Moringa. Journal of Agricultural Technology, 9, 681-689. 
Submit or recommend next manuscript to SCIRP and we will provide best service for you:

Accepting pre-submission inquiries through Email, Facebook, LinkedIn, Twitter, etc. A wide selection of journals (inclusive of 9 subjects, more than 200 journals)

Providing 24-hour high-quality service

User-friendly online submission system

Fair and swift peer-review system

Efficient typesetting and proofreading procedure

Display of the result of downloads and visits, as well as the number of cited articles

Maximum dissemination of your research work

Submit your manuscript at: http://papersubmission.scirp.org/

Or contact ajps@scirp.org 